
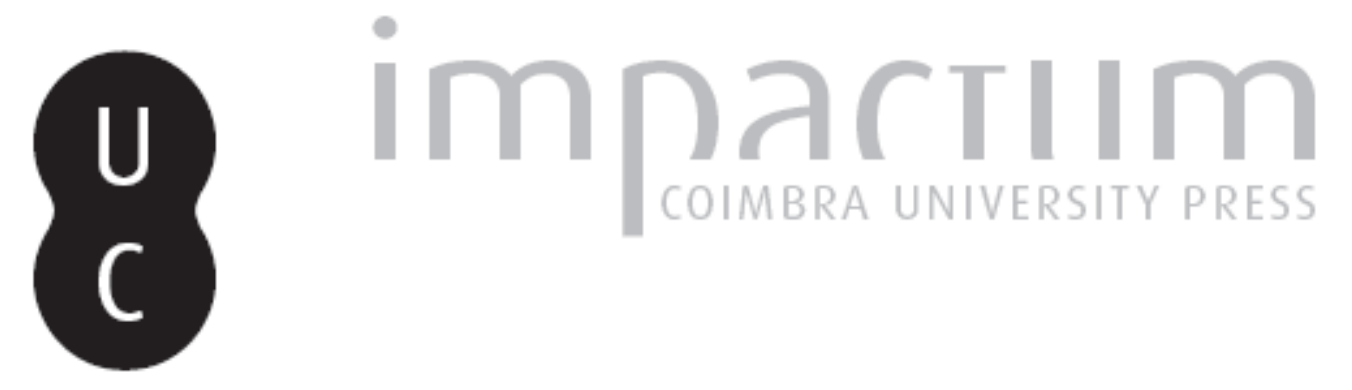

\title{
Espanha, Agosto de 1936: Henrique Galvão enviado de Salazar à Guerra Civil
}

Autor(es): Lemos, Mário Matos e

Publicado por: Imprensa da Universidade de Coimbra

URL persistente:

URI:http://hdl.handle.net/10316.2/44853

DOI:

DOI:https://doi.org/10.14195/1647-8622_18_2

Accessed : $\quad$ 26-Apr-2023 14:39:45

A navegação consulta e descarregamento dos títulos inseridos nas Bibliotecas Digitais UC Digitalis, UC Pombalina e UC Impactum, pressupõem a aceitação plena e sem reservas dos Termos e Condições de Uso destas Bibliotecas Digitais, disponíveis em https://digitalis.uc.pt/pt-pt/termos.

Conforme exposto nos referidos Termos e Condições de Uso, o descarregamento de títulos de acesso restrito requer uma licença válida de autorização devendo o utilizador aceder ao(s) documento(s) a partir de um endereço de IP da instituição detentora da supramencionada licença.

Ao utilizador é apenas permitido o descarregamento para uso pessoal, pelo que o emprego do(s) título(s) descarregado(s) para outro fim, designadamente comercial, carece de autorização do respetivo autor ou editor da obra.

Na medida em que todas as obras da UC Digitalis se encontram protegidas pelo Código do Direito de Autor e Direitos Conexos e demais legislação aplicável, toda a cópia, parcial ou total, deste documento, nos casos em que é legalmente admitida, deverá conter ou fazer-se acompanhar por este aviso.

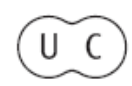




\section{ESTUDOSDOSÉCULO}

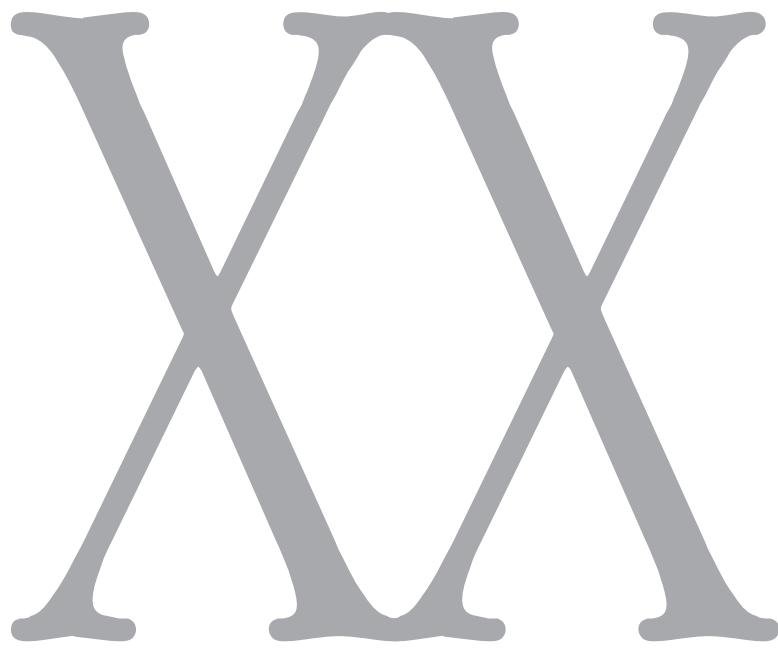

número $18 \bullet 2018$

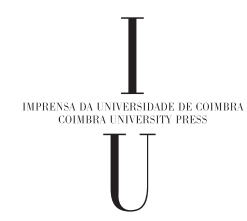




\title{
Espanha, Agosto de 1936 - Henrique Galvão enviado de Salazar à Guerra Civil
}

\author{
Spain, August 1936 - Salazar's envoy \\ Henrique Galvão to the Civil War
}

\author{
Mário Matos e Lemos
}

Mário Matos e Lemos, Licenciado em História pela Faculdade de Letras da Universidade de Lisboa e Investigador colaborador do Centro de Estudos Interdisciplinares do Século XX, da Universidade de Coimbra. Email: matoselemos@gmail.com. 
ESPANHA, AGOSTO DE 1936 - HENRIQUE GALVÃO ENVIADO DE SALAZAR À GUERRA CIVIL

No fim de Julho de 1936, logo no início da Guerra Civil de Espanha, Salazar quis saber, não apenas pelos jornais, mas por um seu homem de confiança, o então Capitão Henrique Galvão, o que se estava realmente a passar. Galvão está durante duas semanas no sul de Espanha, sob a capa de enviado do Diário da Manhã, a acompanhar uma das colunas dos sublevados, a do Comandante Castejón, e escreve sete cartas ou relatórios ao então chefe de gabinete do Presidente do Conselho, Antero Leal Marques dando conta do que ia vendo e emitindo algumas opiniôes.

Palavras-chave: Henrique Galvão, Comandante Castejón, Queipo de Llano, Comunistas, Ephemera.

\section{SPAIN, AUGUST 1936 - SALAZAR'S ENVOY HENRIQUE GALVÃO TO THE CIVIL WAR}

In late July 1936, at the beginning of the Spanish Civil War, Salazar wanted to know what was going on in Spain, not only through the newspapers, but from one of his trusted men, Captain Henrique Galvão. Galvão spent two weeks in the South of Spain, under the guise of Diário da Manhâ's envoy, to accompany one of the rebels' groups, led by Commander Castejón, and thereafter wrote seven letters and reports to the then Chief of Staff of the President of the Council, Antero Leal Marques, reporting on what he saw and giving his opinion.

Keywords: Henrique Galvão, Commander Castejón, Queipo de Llano, Communists, Ephemera.
ESPAGNE, AOÛT 1936 HENRIQUE GALVĀO ENVOYÉ DE SALAZAR À LA GUERRE CIVILE

Fin juillet 1936, tout au début de la Guerre Civile d'Espagne, Salazar a voulu savoir, pas uniquement par les journaux, mais par l'un de ses hommes de confiance, l'alors Capitaine Henrique Galvão, ce qui se passait réellement. Pendant deux semaines, Galvão a accompagné dans le sud de l'Espagne, sous la couverture d'envoyé du Diário da Manhá, l'une des colonnes des soulevés, celle du Commandant Castejón, et écrit sept lettres ou rapports adressés à l'alors chef de cabinet du Président du Conseil, Antero Leal Marque en racontant ce qu'il voyait et émettant quelques opinions.

Mots clés: Henrique Galvão, Commandant Castejón, Queipo de Llano, Communistes, Ephemera. 
Com a implantação da República em Espanha, em 1931, o Governo português passou a seguir com redobrada atenção, os acontecimentos politicos daquele pais. Estava-se em plena Ditadura Militar e, por coincidência, na mesma altura em que a Espanha mudava de regime, os republicanos exilados na Madeira e na Guiné pegavam em armas contra o Governo de Lisboa. Vencida essa revolta, muitos exilaram-se no país vizinho e ai mantiveram intensa actividade conspiratória. O Estado Novo, que em 1933 sucedeu à Ditadura instalada em 1926, manteve uma atitude cautelosa face ao Governo de Madrid mas permitiu que os conspiradores espanhóis circulassem livremente em Portugal ou aqui se exilassem. O levantamento militar de Julho de 1936 despertou o maior interesse em Portugal, tanto no Governo como na imprensa, e todos os jornais diários da capital, com a unica excepção do vespertino República, enviaram imediatamente correspondentes que foram acompanhando as operaçóes militares dos "nacionais", como se dizia, e escreveram longos artigos sobre o que se passava, sempre, aliás, sob o olhar atento dos serviços de Censura. Embora, de maneira geral, os jornais fossem favoráveis aos inssurrectos, a excepção, entre os diários, foi a República, nem por isso deixaram de relatar as atrocidades cometidas por ambas as partes e a que assistiram ou de que tiveram conhecimento, tendo ficado célebre a reportagem de Mário Neves, no Diário de Lisboa, sobre a queda de Badajoz.

Preocupado com a situação, talvez sem total confiança nas informaçôes que lhe chegavam, por via diplomática ou pela imprensa, Salazar resolveu enviar um homem da sua total confiança, o Capitão Henrique Galvão, em busca de um conhecimento mais e seguro. Não terá havido qualquer contacto directo entre ambos, uma vez que as cartas, ou relatórios, como se lhes queira chamar, são dirigidas ao chefe de gabinete do Presidente do Conselho, Antero Leal Marques, com os devidos cumprimentos para Sua Excelência.

Estes documentos encontram-se no blog Ephemera, de José Pacheco Pereira, que se lhes referiu num programa transmitido pela TVI24 no dia 27 de Janeiro de 2018, recordando que os comprara juntamente com outra documentaçâo, também fotográfica, relativa à Guerra Civil de Espanha. Originalmente, foram divulgados na newsletter semanal Ephemera Noticias da Semana (de 29 de Agosto a 4 de Setembro de 2016).

É bem sabido que o Governo de Oliveira Salazar, consciente de que muito provavelmente a vitória dos republicanos significaria a queda do ainda jovem Estado Novo, apoiou, desde o primeiro momento, a sublevação militar, em 1936, embora tivesse mantido alguma reserva e prudência. Terá sido essa prudência que, por exemplo, o levou a impedir que saísse de um aeroporto militar a avioneta que deveria levar para Espanha o General Sanjurjo ${ }^{1}$, exilado em Portugal desde 1932. A fim de chefiar o movimento, Sanjurjo, conspirador activo contra o Governo republicano, deveria partir para Burgos no dia 20 de Julho de 1936, numa pequena avioneta pilotada por Juan Antonio Ansaldo². Todavia, Lisboa ainda mantinha relaçóes diplomáticas com

\footnotetext{
${ }^{1}$ José Sanjurjo Sacanell (1872-1936), Marquês de Rif em 1921, pela sua acção em Marrocos, deveria assumir o comando das forças sublevadas.

${ }^{2}$ Juan Antonio Ansaldo Vejarano (1901-1958) combateu pelos nacionalistas durante a Guerra Civil, foi adido militar de Espanha em Vichy nos anos 40 mas viria a afastar-se de Franco e exilar-se-ia, primeiro em Portugal, depois na Argentina.
} 
Madrid ${ }^{3}$ e Salazar não autorizou que a avioneta saísse de um aeroporto militar, pelo que foi utilizado um quase improvisado aeródromo, em Cascais, um antigo hipódromo abandonado. A aeronave, a mesma com que Ansaldo levara o General Franco ${ }^{4}$, três dias antes, das Canárias para Marrocos, estava demasiadamente pesada e despenhou-se e incendiou-se pouco depois de tirar as rodas do chão, causando a morte do General e ferimentos no piloto. Um acidente que poderá ter mudado a história de Espanha.

Essa mesma prudência, deverá ter levado Salazar a querer informar-se directamente quanto à verdadeira situação militar em Espanha pelo que terá decidido enviar à zona de guerra alguém da sua confiança para examinar in loco, o andamento do conflito.

O escolhido foi o Capitão Henrique Galvão ${ }^{5}$, nessa altura director da estação de rádio oficial, a Emissora Nacional, que seguiu para o sul de Espanha sob a cobertura de enviado do Diário da Manhã, o órgão oficioso do regime. Nesse jornal - que já tinha como enviado especial o jornalista Costa Júnior (a quem se juntou no dia 12 de Agosto o seu colega de redacção Jorge Simões) - foram publicadas várias crónicas suas, embora não assinadas. Em nota à primeira crónica, enviada de Huelva, com data de 1 de Agosto, e publicada no dia 5, o jornal informa que "por expressa determinação do jornalista distinto que desinteressadamente nos quis prestar, neste momento tão preciosa colaboração, estas crónicas não saem assinadas». Galvão confirma na primeira carta que remete, como todas as outras, para o chefe de gabinete de Salazar, Antero

${ }^{3}$ Portugal romperia as relaçóes com a República espanhola no dia 23 de Outubro de 1936.

${ }^{4}$ Francisco Franco Bahamonde (1892-1975).

${ }^{5}$ Henrique Carlos da Mata Galvão (1895-1970), Cadete quando do movimento de Sidónio Pais, Tenente, no 28 de Maio de 1926, defcnsor da Ditadura nos violentos confrontos no Rato, em Lisboa, no 7 de Fevereiro de 1927, em Abril seguinte torna-se um dos redactores principais do diário O Imparcial, patrocinado pelo Ministério do Interior, mas em Agosto desse ano juntou-se ao movimento que ficou conhecido por revolta dos Fifis pelo que foi condenado a degredo em Angola, para onde partiu em Novembro. Aí, foi requisitado como chefe de gabinete do Alto-Comissário, entâo o Major de engenharia e antigo Ministro das Finanças António Vicente Ferreira (1871-1953) e depois nomeado governador da Huíla, cargo que desempenhou entre Fevereiro e Junho de 1929, até o novo Alto-Comissário, Filomeno da Câmara (Filomeno da Câmara de Melo Cabral, 1873-1934), o exonerar. Regressou a Lisboa, foi Comissário da Exposição Colonial do Porto, em 1934, e presidente da primeira comissão administrativa da Emissora Nacional (1935-1941). Deputado à Assembleia Nacional por Angola (1945-1949), cargo em que náo foi reconduzido, apesar de indicado por Salazar, por oposição do Ministro da Colónias, Capitão Teófilo Duarte (1898-1958). Coloca-se depois contra o regime, apoia a candidatura do Almirante Quintão Meireles à Presidência da República, em 1951, e é preso no ano seguinte, acusado de «actividades conspiratórias». Julgado e condenado em Março de 1953, cumpriu um ano mas no dia em que foi libertado (8 de Outubro de 1954) a PIDE voltou a detê-lo, agora sob a acusação de, enquanto preso, ter escrito artigos «subversivos» para jornais brasileiros Julgado de novo, é condenado a 16 anos de prisáo mas evade-se (Janeiro de 1959) e refugia-se na Embaixada da Argentina em Lisboa, de onde segue, em Maio, para a América do Sul. Organiza, com um grupo de espanhóis antifranquistas, o assalto ao navio de passageiros "Santa Maria», em Janeiro de 1961. Em 1963, presta declaraçôes nas Nações Unidas sobre a questão ultramarina portuguesa mas desilude os oposicionistas pois revelou-se defensor do Ultramar português. Entra depois em divergência com outros exilados portugueses, designadamente rompe com o General Humberto Delgado, até que a doença o afasta da actividade política. Como escritor, deixou uma importante obra sobre temas ultramarinos, designadamente sobre Angola. 
Leal Marques ${ }^{6}$, datada de 2 de Agosto, que tem enviado crónicas para aquele jornal ${ }^{7}$ e organizado informaçóes pela rádio acrescentando que nesse mesmo dia 2 forneceu, «às 13 horas, a primeira informação radiofónica que devia ter sido registada na Emissora, conforme as instruçôes e cifra que lá deixei». Garante também que conserva «a maior reserva» acerca da sua "posição oficial, actuando como um simples jornalista». Não tão "simples», dir-se-ia: ao chegar a Sevilha, dirige-se ao consulado, cujo titular, António de Cértima, ${ }^{8}$ em ofício dirigido ao Presidente do Ministério ${ }^{9}$, comunica que Galvão se encontra a acompanhar a coluna do comandante Castejón ${ }^{10}$ " destinada a submeter os grupos marxistas que dominam em Badajoz e a seguir em direcção a Madrid onde estabelecerá ligação com as forças do General Mola ${ }^{11} \gg .^{12}$

No espaço de duas semanas, Henrique Galvão dirigiu sete cartas, todas manuscritas, a Leal Marques. Estão datadas de 2, 4, 6-7, 8, 9, 13 e 17 de Agosto $^{13}$ e incluem, designadamente, relatos de conversas com os generais Queipo de Llano ${ }^{14}$ e Franco e

\footnotetext{
${ }^{6}$ Antero Leal Marques (1880-1969), foi chefe de gabinete de Salazar entre 1928 e 1940, primeiro no Ministério das Finanças, depois na Presidência do Conselho.

${ }^{7} \mathrm{Na}$ carta do dia 9 pede mesmo a Leal Marques que mande «fornecer ao Diário da Manhã todas as notícias destes relatórios que não forem inconvenientes para publicação».

${ }^{8}$ Jornalista e escritor (1894-1983) baptizado como António Augusto Gomes Cruzeiro. Em 1926 foi nomeado vice-Cônsul em Suez, tendo sido depois Cônsul em Dakar (1927-1932) e seguidamente em Sevilha, onde permaneceu até 1949. Combateu em África durante a primeira Guerra Mundial e sobre essa experiência publicou, em 1924, uma obra marcante: Epopeia Maldita - O Drama da Guerra d'África, em que relata as terríveis condiçóes de vida dos expedicionários portugueses.

${ }^{9}$ Era, desde 11 de Abril de 1933, António de Oliveira Salazar. Note-se que um Cônsul não se dirige directamente ao Chefe do Governo mas sim ao Ministro dos Negócios Estrangeiros, que era Armindo Monteiro (1896-1955). Fê-lo, como ele próprio escreve, "por incumbência do sr. Capitão Henrique Galvão".

${ }^{10}$ Antonio Castejón Espinosa (1896-1979) militar de Infantaria, chegara a Sevilha, vindo de Marrocos, de avião, com uma Companhia da Legião, entre 19 e 20 de Julho. É considerado um dos mais duros chefes militares nacionalistas. General no fim da guerra, foi, em 1957, designado Capitão-General da II Região Militar de Espanha, com sede em Sevilha.

${ }^{11}$ Emilio Mola Vidal, nascido em 1897, morreria num acidente aéreo em 1937.

${ }^{12}$ No mesmo ofício (ANTT - AOS//CO/NE - 9 I, pp.79-80), Cértima informa ter apresentado Galvão «ao enérgico General Queipo de Llano» e aproveita para informar Salazar sobre «os acontecimentos que se estão desenrolando em Espanha». Escreve: «Rogo a Vossa Excelência prévia autorização para ter a honra de informar que se prevê para muito breve a queda dos governos de Madrid e Barcelona, dando a vitória ao exército Nacionalista espanhol. Não poderei igualmente deixar de acentuar o entusiástico movimento de simpatia para com Portugal que se manifesta em toda a população desta cidade. Notas da imprensa têm chamado a atenção do público para a gratidão com que a Espanha deve receber neste momento todas as manifestações de amizade da Nação Portuguesa. E assim é que, desde alguns dias, um público numeroso, constituído por todas as classes sociais, desfila constantemente por este Consulado deixando cartões e cartas onde se lêem as frases mais carinhosas e vibrantes, tanto para com a Nação Portuguesa, como para com o glorioso creador do Estado Novo.»

${ }^{13}$ Como se disse, estão publicadas no blog Ephemera, do doutor José Pacheco Pereira, com uma nota de agradecimento a "Maria Faustino pelo trabalho realizado na transcrição" dos documentos e a promessa de serem "posteriormente anotados pela sua importância histórica como documentos oriundos de um observador privilegiado do lado dos sublevados».

${ }^{14}$ Gonzalo Queipo de Llano y Sierra, Marquês de Queipo de Llano (1875-1951). No dia do levantamento, encontrava-se em Huelva, na qualidade de Inspector-Geral dos Carabineiros sem comando de tropas, portanto. Escapou para Sevilha, onde se apoderou do comando da guarniçáo, cuja oficialidade hesitou na atitude a tomar: pró ou contra os sublevados. Seria peça fundamental do alzamiento nos seus primeiros dias, tanto sob o ponto de vista militar como pelo seu papel na propaganda nacionalista.
} 
referências a operaçóes de guerra, não escamoteando a enorme violência da repressão nem poupando críticas à condução militar da guerra. Todavia, nas crónicas que envia para o Diário da Manhã , desenvolve muito mais os aspectos narrativos e insiste nas «atrocidades comunistas» e na ausência de operários entre os comunistas.

$\mathrm{Na}$ primeira carta, dirigida a Leal Marques "para conhecimento de S. Exa ${ }^{a}$. O Presidente do Conselho», Henrique Galvão começa por pedir "desculpa» pelo "estilo necessariamente telegráfico", acrescentando: "Todo o tempo é pouco e resta muito pouco para escrever", o que não se coaduna muito bem com as extensas crónicas que envia para o jornal. Descreve, depois, como chegou a Sevilha, vindo de Vila Real de Santo António, no Algarve, fazendo parte do percurso de camioneta entre Ayamonte e Huelva onde, sem qualquer meio de transporte, conseguiu um cavalo para percorrer 30 quilómetros até apanhar um comboio de mercadorias que o deixara, nessa manhã, na capital andaluza. Explica que essa dificuldade de transporte "não reflecte exactamente a verdade do que se observa em tudo o mais: ordem, serenidade e absoluta confiança no triunfo do movimento" pois "ninguém duvida do êxito mas ninguém duvida também que levará o seu tempo porque o mal era já muito extenso e estava muito generalizado». Traça depois o perfil do General Queipo de Llano com quem conversou - diz - logo à chegada e que pôs à sua disposição "os microfones dos postos nas regiões libertadas»; salienta que «contra o [que] esperava» o General lhe deixou «a melhor das impressôes», acrescentando: "Não sei porquê, através das proclamaçóes que ouvia fiz uma ideia diferente daquela [com] que fiquei depois de ter falado com ele. Sáo impressionantes a sua calma e confiança. Assisti a algumas da suas decisóes: precisas, claras, rápidas. Pareceu-me, além disso, ser pessoa de vasta cultura e que sabe o que quer.» Essa conversa, foi publicada no Diário da Manhâ, sob forma de entrevista, consideravelmente desenvolvida em relação ao que está na carta, nos dias 5 e 8 de Agosto, mas com datas de, respectivamente, 2 e 3 e em ambos os casos na primeira página do jornal.

Há ainda uma nota curiosa: observa Galvão que «o elemento operário passeia pela cidade fazendo manifestaçóes e procurando convencer que o movimento é comunista mas não operário».

$\mathrm{Na}$ segunda carta, escrita de Llerena, com a data de 4 de Agosto, Galvão informa ter saído de Sevilha com a coluna do «célebre» Comandante Castejón (do Tercio ${ }^{15}$ ), que iria» pela fronteira portuguesa, concluir a ocupação da região de Mérida e Badajoz, seguindo imediatamente para Madrid onde completará o cerco da cidade para a ocupação decisiva». Galvão - tal como os seus interlocutores - mostra-se confiante na vitória dos sublevados: «Se quem está em Portugal pode ter quaisquer dúvidas sobre o resultado do movimento por causa da demora que tem havido em liquidá-lo - essas dúvidas são impossíveis aqui. $\mathrm{O}$ movimento está virtualmente triunfante e a tomada de Madrid pouco mais será do que a chancela posta sobre a vitória. De resto, nem sequer há inimigo que ofereça resistência. Nas cidades que os governamentais ainda ocupam o simples aparecimento da coluna fá-los entregar. E as manifestaçôes das populaçóes libertadas são delirantes.» Conclui mais adiante: «Creio que Madrid não será ocupada

${ }^{15}$ Tipo de unidade militar criada por Carlos V em 1534. Voltou a ser usada esta designação, a partir da década de 20, do século xx, na Legião Espanhola. 
antes da próxima semana - mas que na próxima semana será com certeza» ${ }^{16}$. Todavia, Galvão, na mesma carta, face ao que já ouvira e vira, afirma não acreditar «numa rendição fácil» da capital pois os seus defensores e «não só os comunistas propriamente ditos como também os esquerdistas menos avançados, sabem a sorte que os espera» pelo que "preferirão morrer lutando».

Propriamente sobre a tomada de Llerena - objecto de extensa crónica remetida ao Diário da Manhã pelo seu «enviado especial que segue com a coluna Castejón»»»- , datada de 5 e publicada no dia 12, Galvão limita-se a um parágrafo na sua carta de 4: «acabo de assistir à tomada de Llerena, nos arredores de Badajoz e no caminho de Madrid. Os comunistas foram completamente envolvidos. 300 presos que estão sendo revistados e a seguir serão fuzilados. Esperam-se mais pois há emboscadas nas estradas por onde poderiam fugir. Prometeram-me mostrar-me todos os papéis encontrados que refiram ligaçóes com os comunistas portugueses. Sobre este assunto, o comandante da polícia de Sevilha fez-me revelaçôes interessantes que não me atrevo a confiar a um relatório que pode não chegar ao seu destino.»

\section{Testemunha da repressão}

Ao referir que «as atrocidades cometidas são espantosas», acrescentando que "a repressão corresponde-lhes inteiramente», Galvão acolhe piamente as informaçôes que lhe são dadas e informa, logo na primeira carta: "Como julgo útil dar-lhes a maior publicidade pô-las-ei em relevo nas crónicas para o D. (Diário) da Manhá.»

A duríssima repressão a que assiste a ele próprio impressiona, embora pareça concordar, numa lógica de "olho por olho»:

"A repressão é tremenda - escreve na carta do dia 4 - e corresponde inteiramente às atrocidades cometidas pelos comunistas. Basta uma simples suspeita de esquerdismo para que o fuzilamento seja inevitável [?]. Por sua vez, a série de fuzilamentos vai instituindo o hábito de matar. Tenho assistido a vários. Ontem, pouco depois de sairmos de Ronquillo ocupada, a coluna parou para executar 30 pessoas. As mulheres não são mais poupadas do que os homens. Há pouco foi presa a mulher dum tenente comunista que conseguiu escapar. Ela pagará por ele.»

Logo no dia 2 de Agosto refere a sorte do Governador de Huelva: «O grande amador do comunismo nesta cidade que tinha fugido, foi ontem preso. Será fuzilado amanhã de manhã, apesar da sua alta patente militar. A pena de fuzilamento é fatal para todos os que são encontrados com armas na mão. Em Sevilha, fuzilam-se todos os dias dezenas de pistoleiros.» ${ }^{17}$ No mesmo dia refere uma "operação importantíssima na direcção de Málaga com o objectivo de cortar o nó estratégico de comunicaçôes», tendo sido mortos no combate «300 comunistas». No dia 6, está de novo em Sevilha,

\footnotetext{
${ }^{16}$ Para esta prematura nota de optimismo sobre o rápido desfecho da guerra terá contribuído o facto de Galvão ter assistido à rendição, sem luta, de cidades cujas guarniçóes não se haviam revoltado .

${ }^{17}$ Castejón, na entrevista que o Diário da Manhä publica, apresenta a razão, por que entende proceder a todos esses fuzilamentos «A verdadeira piedade consiste em poupar as vidas que a morte de cada pistoleiro vai poupar».
} 
onde voltou, para tratar de um ferimento ${ }^{18}$ «deixando por uns dias a coluna Castejón». No dia 8, ainda em Sevilha, informa que «o número oficial de fuzilamentos no sul vai em 30.000 [e] não me repugna acreditá-lo em face do que vi» (na véspera, recorda, «numa hora vi fuzilar mais de cem. E com uma facilidade, um prazer, que garantem o número oficial»); acrescenta que «dizem que em toda a Espanha atinge já 80.000 só os realizados pelas forças do Exército" mas «apesar disto os focos comunistas que ainda existem não desarmam e resistem tenazmente».

No dia 9, relata novos fuzilamentos: «Hoje foram fuzilados em Sevilha 72 homens e entre eles advogados, médicos, jornalistas e militares das esquerdas», havendo casos em que "ficam umas horas em exposição para exemplo»; e comenta: «as atrocidades dos comunistas são horríveis mas a repressão corresponde-lhes inteiramente.»

\section{Encontros com Franco}

Francisco Franco desembarcou em Espanha, no dia 6 de Agosto, vindo de Marrocos, e dirigiu-se imediatamente a Sevilha. Galvão, na carta do dia 8, informa que se avistará nesse mesmo dia com o General, que - escreve - vinha para «se instalar definitivamente» acompanhado pelo seu Estado-Maior de que «fazem parte oito oficiais alemães que agem sem a menor reserva». Observa Galvão que «o acontecimento tem produzido um grande entusiasmo na população que, sem dúvida, vê em Franco o seu chefe de confiança; a chegada de Franco é tida por todos como decisiva para a liquidação do movimento.» Todavia - prossegue Galvão - «é voz corrente que ele e o General (Queipo de) Llano já não se entendem, sendo um dos motivos da discórdia a excessiva loquacidade deste. O General Queipo de Llano está perdendo um pouco a popularidade. Acusam-no de ter sido maçon e ter trabalhado para a República. A estrela agora é o General Franco».

A entrevista com Franco parece só se ter concretizado no dia seguinte, pois é na carta do dia 9 que informa:

«Falei hoje com o General Franco durante uma hora. Está preparando as cousas para o ataque decisivo sobre Madrid. De Marrocos já vieram quase todas as tropas do Tercio. O objectivo é tomar Madrid com o mínimo de prejuízo para a cidade e para a populaçáo civil. Falou longamente do seu programa que segue de perto o das ditaduras europeias, sem nada mais de original como é natural e afirmou que se inspirava nos princípios corporativos do Estado Novo português.»

Relata depois a impressão que o General lhe causara:

«Embora mo não confessasse, percebi nitidamente que é um monárquico que dificilmente transige com o regime republicano. Mas percebe-se igualmente que é acima de tudo um militar a quem só têm interessado as questóes militares. Claro e preciso - quase eloquente - quando fala das suas operaçóes, é confuso e hesitante quando se refere ao seu pensamento político. Dá-me a impressão de que fala sobre leituras feitas à pressa e mal digeridas. Fiquei também com a impressão de que as operaçóes dirigidas por ele ganharão em poder militar e em organização. O próprio Quartel-General que

${ }^{18} \mathrm{Na}$ sua carta de 13 de Agosto, Galvão afirma já estar «completamente curado do ferimento que recebi em Llerena». 
instalou num magnífico palácio dá impressão de ordem e eficiência - ao contrário do Quartel-General de (Queipo de) Llano, que parece um formigueiro onde toda a gente entra e sai quando e como quer.»

Na carta remetida de Sevilha no dia 13 informa ter falado de novo com Franco: «Deu-me notícias acerca de Badajoz. Disse que esperava para hoje a queda da cidade e explicou que a razâo da demora ${ }^{19}$ está no facto dos sitiantes pretenderem evitar a todo o custo a destruição da cidade e o massacre da populaçáo civil indefesa. Os bombardeamentos têm incidido apenas sobre a fortaleza e a praça de touros, onde as informaçôes dizem que os comunistas se concentravam.»

Acrescenta ter dado uma sugestão:

«Na conversa que tive com o General Franco disse-lhe o pouco que sabia da atitude das potências perante o caso espanhol e sugeri a vantagem que possivelmente existe para o governo militar em fazer larga e clara publicidade pela fotografia, pelo cinema e pela imprensa na Inglaterra sobre as atrocidades cometidas pelos comunistas. Julgo que a Inglaterra não está muito convencida da gravidade do caso espanhol e que uma acção sobre a opinião pública inglesa seria favorável aos revoltosos. O General mostrou-se interessadíssimo pela ideia que, disse, iria pôr imediatamente em prática.»

Náo seria a primeira sugestão que dava. $\mathrm{Na}$ carta do dia 7 , talvez por via da sua preocupação com a lentidão das operaçóes, de que se queixa, como se verá abaixo, informa o seguinte:

«Em conversa com Queipo de Llano sugeri-lhe a vantagem de fazer ocupar quanto antes a pequena parcela de território que ainda está povoada por revoltosos, confinante com Portugal na província de Badajoz. O objectivo da coluna Castejón não compreendia a ocupação de toda esta região à qual, por via do isolamento em que está, não atribuíam grande importância. Insisti na minha sugestão pois julgo que seria preferível não haver qualquer solução de continuidade nas zonas ocupadas ao longo da fronteira nem corredores comunistas. O General concordou e mesmo na minha presença mandou expedir ordens terminantes a Castejón para que a cidade de Badajoz e Mérida (esta que já está investida) sejam tomadas e ocupadas. O acontecimento deve verificar-se hoje ou amanhã - talvez amanhã porque há muitas pontes destruídas na região. ${ }^{20}$

\section{Critica à conduçáo das operaçóes militares}

Galvão é muito crítico relativamente à condução militar de guerra: «Noto uma certa desorganização nas forças militares o que também não explica a pouca eficiência destas operaçôes» escreve logo no dia 2. Em 4, observa que «apesar de tudo», acha «francamente lentas as operaçóes, lentidão que se justifica até certo ponto pelos motivos que já expliquei mas também é certo que se perde muito tempo». Dois dias depois observa ainda com maior contundência:

\footnotetext{
${ }^{19}$ Badajoz caiu no dia 14 de Agosto. À chegada a Espanha. Galvão tivera uma informação errada e, na primeira carta, dera Badajoz como tomada, confirmando "a notícia que deu a Emissora»

${ }^{20}$ A conversa terá sido a do dia 2 pois no dia 4, como se diz acima, informa, de Llerena, ter saído com a coluna de Catejón para ocupar a regiâo de Mérida e Badajoz.
} 
«Cada vez tenho mais radicada a impressão de desorganização e de crise de comando. A coluna Castejón, por exemplo, que dispóe de todas as condiçóes materiais de mobilidade e que representa hoje um elemento de primeira ordem entre os recursos militares dos revoltosos, não tem rendimento de avanço superior a $30 \mathrm{~km}$ por dia quando podia realizar sem dificuldade 80 . Tudo é lento por desorganização e falta de comando. Não há um inimigo no sentido militar da palavra porque se houvesse as cousas seriam bastante duras [?]. Durante a marcha da coluna até Llerena, dezenas de vezes atravessámos situaçóes em que um pelotão de desordeiros nos desbaratariam ... se tivessem umas luzes de conhecimentos militares.»

Volta ao assunto no relatório do dia 9: «Tudo é lento, infinitamente lento e sem razão para ser tão lento. Há cousas que quer sob o ponto de vista militar, quer sob o ponto de vista político. são incompreensíveis - e entre elas a falta de espírito ofensivo de certas colunas com todas as condiçôes militares de progredirem rapidamente.»

Impressão que confirma no dia 13: "Continuo a observar a mesma lentidão por vezes inexplicável e nitidamente contrária a certos objectivos militares que desde o princípio tenho notado nas marchas e operaçóes das colunas revoltosas.»

Na última carta, datada de 17 , volta ao tema:

«As acções militares, na tomada de Badajoz e Mérida confirmam em absoluto tudo quanto tenho referido acerca do espírito de indecisão dos comandos. Não existe uma razão militar aceitável para a lentidão com que as operações decorrem. As colunas são dotadas de magníficos elementos de mobilidade e dispóem de material magnífico. Os seus trens de muniçôes são abundantíssimos. As razões invocadas para justificar as demoras, tais como desejo de poupar as cidades e as populações só quem não viu o que se passa as pode aceitar. Têm que tomar-se como as razóes políticas para o exterior e nada mais. Na prática, as cidades são destruídas da mesma forma e as populaçôes sacrificadas - talvez mais (decerto mais) do que se as operaçóes decorressem com a decisão própria das operaçôes militares em casos análogos ao presente.» Sem modéstias, conclui: «Tenho verificado que com muito menos elementos não me seria difícil nem complicado agir mais eficazmente em muito menos tempo.»

Propóe, no dia 8, «a presença de um observador militar junto do General Franco e explica porquê: «O que tenho visto e observado nas operaçóes militares a que tenho assistido é por vezes tão extraordinário e tão significativo que julgo o momento excepcional para uma observação que dificilmente nos seria dada noutras circunstâncias. Agora que se está a olhar a sério para as nossas cousas militares creio que nos interessa enormemente uma avaliação das possibilidades militares de Espanha [...] Estou convencido [de] que esse observador (uma espécie de adido militar) levaria daqui informaçóes preciosas e, sob certos pontos de vista, talvez surpreendentes.»

\section{O apoio alemão e italiano e o desejo de receber mais apoio de Portugal}

Os relatórios que Galvão envia durante pelo menos duas semanas estão polvilhados de informações sobre o apoio que os sublevados recebiam da Alemanha e da Itália ${ }^{21}$.

\footnotetext{
${ }^{21}$ Estes dois países reconheceram formalmente o Governo de Burgos em 18 de Novembro de 1936. $\mathrm{Na}$ carta do dia 9 de Agosto, Galvão informa terem chegado ao aeródromo de Tablada «cinquenta aviōes
} 
«Tenho a impressão - escreve Galvão logo no dia 2 - de que dispóem de bons e numerosos elementos materiais, apesar do que se crê lá fora. A Itália sobretudo auxilia com bastante clareza os revoltosos. O Cônsul de Itália está permanentemente no gabinete de Queipo de Llano e vêem-se numerosos italianos na cidade.»

No dia 6 insiste: «O Cônsul italiano está quase permanentemente junto do General Queipo de Llano. Vive no mesmo hotel em que me encontro e é frequentemente chamado pelo General a conferências telefónicas.» A carta do dia 17, a última, refere o «almoço oferecido pelos oficiais espanhóis à oficialidade do cruzador italiano Antonio da Noli que veio a Sevilha» e a que "assistiram os Generais Queipo de Llano (que presidiu) e Millan-Astray ${ }^{22}$, o comandante do cruzador e oficiais, o Cônsul de Itália, o Alcaide de Sevilha e numerosos oficiais». O almoço decorreu no Hotel Madrid, no qual Galvão se hospedava, e que por isso pôde acompanhar «sentado numa mesa próxima». Observa que «embora se pretendesse guardar fragilmente as aparências, apresentando o banquete como uma manifestação de solidariedade entre espanhóis e italianos, o que é certo é que a publicidade que se lhe deu, a presença dos generais e dos cônsules e, sobretudo os discursos pronunciados, constituíram um verdadeiro reconhecimento formal e entusiástico por parte da Itália». Refere os discursos proferidos, primeiro por Millan-Astray («discurso inflamado de legionário, um desses discursos que em Portugal seriam impossíveis sem cobrir o orador de ridículo»), depois pelo comandante do cruzador («embora mais sóbrio o discurso foi bastante lírico e provocou quentes manifestaçóes a que se associaram os hóspedes, franceses, ingleses e italianos, que comiam noutras mesas»). Por fim, falou Queipo de Llano que "principiou por dizer que usava da palavra a pedido do Cônsul de Itália» e que terminou com «brindes à Itália, ao seu Rei, a Mussolini, de quem fez um elogio caloroso, e a Portugal». Cita misturando português e espanhol: «Durante este momento Espanha contrajo lazos de amistad entre la hermana Italia y la hermana Portugal, lazos que nunca mais se podem quebrar.»Enquanto os assistentes cantavam a Giovinezza, ${ }^{23}$ Queipo de Llano levantou-se depois e dirigiu-se à mesa onde ele se encontrava "com alguns portugueses», oferecendo-lhes champagne e proferindo "palavras amáveis para nós», das quais destaca uma pergunta: "Quando permitem os senhores que lhes façamos uma festa como esta?»

Não era, segundo Henrique Galvão já referira, a primeira vez que Queipo de Llano manifestara interesse no empenhamento de Portugal ao lado dos revoltosos. Na primeira carta, a de 2 de Agosto, na conversa do português com o General, este perguntara: «Porque não reconhece o Governo português imediatamente a Junta Revolucionária? ${ }^{24}$ » e

alemães adquiridos pelos revoltosos» acrescentando um pormenor: «Os aviadores dizem que o seu objectivo imediato é a destruição dos avióes de Madrid para impedirem a fuga dos dirigentes. Não se pensa senão em liquidá-los. Ouvem-se ameaças por toda a parte - e o certo é que elas se cumprem sempre que é possível.»

${ }^{22}$ José Millan-Astray y Terreros (1879-1954) oficial do Exército, grande mutilado de guerra, ajudou a fundar, em 1920, a Legião Espanhola (inspirado na Legião Estrangeira francesa, cuja organização foi estudar à Argélia), e de que foi o primeiro comandante, com a patente de Tenente-Coronel, tendo como ajudante o entâo Comandante (Major) Francisco Franco.

${ }^{23}$ Hino composto em 1909 que em 1925 se tornou no hino do Partido Fascista italiano.

${ }^{24}$ Em 24 de Julho de 1936, o General Mola constituiu a Junta de Defesa Nacional, com capital em Burgos. Portugal como se disse (Nota 3) só viria a cortar relaçóes com o Governo de Madrid, três meses depois, em 23 de Outubro, só nomearia um Agente Especial, Pedro Theotónio Pereira, em 13 de Dezembro de 1937 e só reconheceria de jure o Governo de Burgos em 28 de Abril de 1938. 
explicara: «Estamos combatendo um inimigo comum. Se os marxistas vencem, Portugal está seriamente ameaçado. Se não vencem (e não vencerão, afirmou) Portugal terá todas as vantagens da posição política que antecipadamente tinha tomado.» Face à reposta de Galvão ( «não conheço nem me compete conhecer as razóes que levam Portugal à sua atitude. Sei que sejam quais forem acho que estão bem e sei que elas são sempre muito poderosas e justas»), Queipo de Llano teria entáo observado que Galvão náo o compreendera «se julgava ver nas suas palavras qualquer censura», acrescentando: «era apenas um desejo" pois "ninguém melhor do que ele reconhecia os grandes serviços que Portugal estava prestando à sua causa e lhes enaltecia o valor, tanto assim que já mais que uma vez afirmara que um dos primeiros gestos do governo triunfante será elevar numa das principais praças de Sevilha ${ }^{25}$ um monumento ao povo português». E terminara: «Assim nós encontremos também nuestro Salazar».

Galvão, aliás, mostra-se a favor do reconhecimento e na carta do dia 6 expóe a sua opinião: "Com os dados, certamente insignificantes, de que disponho, vejo grandes vantagens nesse reconhecimento. Creio que os dirigentes revoltosos, e que são fatalmente os dirigentes do governo espanhol de amanhã, concederiam vantagens importantes contra o seu reconhecimento. A posição política que marcaríamos junto da Espanha seria enorme, pelo menos durante algum tempo. E se esse reconhecimento fosse negociado contra vantagens estudadas e bem formuladas, creio que seria um golpe hábil.» Prudentemente, acrescenta: «Todavia, os elementos de formação de qualquer juízo de que disponho são insuficientes e compreendo que possa não ser bem visto o que daqui me parece táo claro.»

\section{Os problemas políticos}

Henrique Galvão várias vezes se refere aos problemas políticos resultantes da guerra.

Na carta de Sevilha datada de 6-7 de Agosto, observa:

«Continuo convencido de que a questão política que vai levantar-se a seguir à vitória será tremenda. A questão da abundância de chefes e da falta de um chefe. Depois, pelo que tenho ouvido, creio que a questão social ficará de pé. Por quanto tempo? Comunistas é natural que desapareçam de Espanha por algum tempo pois não é difícil crer em face do que tenho visto que o número de fuzilamentos já tenha excedido 30.000.» Esta ideia é reafirmada na crónica sobre a tomada de Llerena publicada no diário da Manhã no dia 11 de Agosto: "A repressão corresponde às violências marxistas. Em Llerena vi fuzilar cem homens. Não creio que fiquem em Espanha comunistas para fazer uma desordem de aldeia.»

Mais adiante, na mesma carta de 6-7, Galvão prevê problemas políticos futuros, salientando:

«A confusão política vai-se acentuando. Surge a questão monárquica. Enquanto uns desejam apenas considerar dois campos - o fascista e o comunista - independentemente

\footnotetext{
${ }^{25}$ Esta ideia, embora não exactamente com as mesmas palavras, será referida também na crónica para o Diário da Manhã. Na versão do jornal, Queipo de Llano propóe levantar o monumento não em Sevilha especificamente mas «numa das principais praças de Espanha», explicando: "Portugal e o seu povo compreendem bem que estamos aqui a combater um inimigo comum.»
} 
da forma de regime e aceitando o actual porque é o que está, outros agitam-se para um regresso à monarquia.

Ainda na mesma carta:

«A confusão política de amanhã continua a desenhar-se cada vez melhor. Perante a chegada de Franco, discutem-se já questões de mando entre os chefes. Para se comporem as coisas, por agora não há um chefe do movimento - isto é: um chefe dos chefes - mas sim vários em funçôes independentes (como eles dizem) apesar de eu não compreender como essa independência possa existir. Mola será o comandante das forças que sitiam Madrid; Queipo de Llano o comandante da Divisão da Andaluzia; Franco o Comandante em Chefe das Forças Militares. Franco é o menos graduado dos generais mas é o mais prestigioso e o mais sabedor. Julga-se evitar conflitos dando a cada um títulos trabalhosamente imaginados e afirmando a independência das suas funçóes.

«Entretanto, embora todos clamem contra os políticos profissionais e digam que a nova Espanha tem que se organizar sem eles - os partidos começam a formar-se e a diferenciar-se [...]. Simplesmente aqui a questão monárquica assumirá uma importância maior: já aparecem nalguns automóveis pequenas bandeiras monárquicas e nas janelas vêem-se senhoras costurando (?) na bandeira bicolor da Espanha monárquica.»

A carta do dia 17, a última - a náo haver mais, como o Ephemera ressalva - termina assim:

«Diz-se que o Governo português entregou aos ocupantes de Badajoz os comunistas que fugiram para Portugal. Essa atitude tem sido enaltecida.»

Em conclusáo: se da leitura destas cartas que a Ephemera divulgou náo se tiram quaisquer novidades, não quer dizer que sejam desprovidas de interesse. Muito pelo contrário: dá o clima que se vivia no sul de Espanha nesses primeiros dias da sublevação contra o Governo de Madrid. Galvão enganou-se quanto à queda de Madrid em pouco tempo, como, aliás, todos previam, mas as suas informações não só ajudaram, via Diário da Manhã, a modelar a opiniáo pública sobre a guerra, como poderão ter ajudado Salazar a formar uma opiniáo sobre o que deveria fazer relativamente ao conflito. Pelo menos, nessa altura, ele certamente gostaria de pensar que sim.

Nota - O autor não segue o $\mathrm{AO} 90$. 